\section{God ny bok om seksualitet}

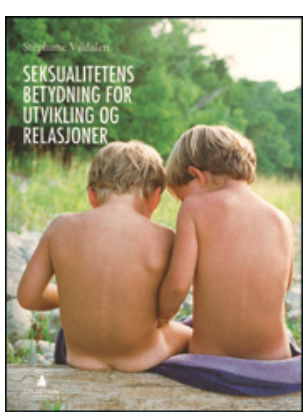

Stéphane Vildalen

Seksualitetens betydning

for utvikling og relasjoner

249 s, tab, ill. Oslo: Gyldendal Akademisk,

2014. Pris NOK 399

ISBN 978-82-05-41012-1

Seksualiteten satt inn i et utviklings- og relasjonsperspektiv knytter denne utgivelsen til samfunns-, psykologi- og sexologifagene. Forfatteren ønsker å få satt opp seksualitet på studieplaner og pensumlister, noe som i dag fortsatt er fraværende. Det ligger i kortene at hun tenker på studenter både innen helse-, pedagogikk- og sosialfagutdanningene.

Forfatterens intensjon er todelt: For det første vil hun vise at seksualiteten er tett integrert i menneskets utvikling og dets relasjoner, der seksualitetens hovedfunksjon er å danne relasjoner som sikrer overlevelse gjennom ivaretakelse, god psykisk og fysisk helse og reproduksjon. For det andre vil hun gi en gjennomgang av psykolog og sexolog Thore Langfeldts 40-årige banebrytende bidrag innen sexologien.

Det er tre deler. Den første delen omhandler seksualitet som et grunnleggende relasjonelt fenomen, integrert i den generelle utviklingen fra menneskets fødsel til død. I del to belyser og problematiserer forfatteren seksuelle overgrep. Forståelsen for hva overgrep er, utvides og avklares. I tillegg til overgrep mot barn og eldre drøftes overgrep satt i system, for eksempel gjennom lovverk eller krig. Hun utdyper hvem overgriperen er. I den tredje og siste delen påpeker forfatteren behovet for en ny forståelse av seksualitet og implikasjonene dette har for samarbeid mellom læreinstitusjoner og helsevesen. Hun retter søkelyset mot den manglende sexologiske kunnskapsformidlingen i utdanningene.

Dette er en god og viktig bok både for fagfolk og utdanningenes studieplaner. I tillegg til å se seksualiteten som integrert i menneskets generelle utvikling og relasjoner, defineres den inn i samspillet mellom menneskets biologi og psyke. Dette synliggjør nødvendigheten av å ta hensyn til seksualiteten når man skal hjelpe mennesker, uavhengig av i hvilken livsfase eller situasjon mennesket befinner seg.

To agendaer, det kan virke forvirrende, selv om innholdet $\mathrm{i}$ begge uløselig hører sammen. Studenter utenfor sexologistudiene er antakelig mindre opptatt av historikk og utvikling av sexologi som fag. De jakter snarere på konkret stoff som bidrar til kunnskap og forståelse for bedre å kunne hjelpe pasientene de møter i sin kliniske praksis. Og det finner de her.

Boken er viktig og nyttig både for leger, andre fagfolk og studenter. Den bør absolutt ikke bli oversett - verken som fag- eller pensumbok.

\section{Haakon Aars}

Spesialist i psykiatri, Institutt for klinisk sexologi og terapi Oslo

\section{Sjarmerende Roma-reise}

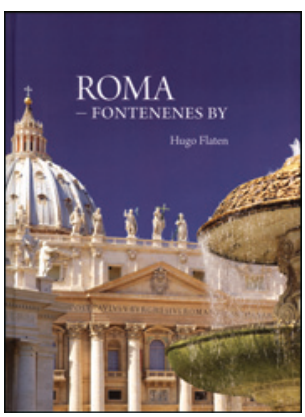

\author{
Hugo Flaten \\ Roma - fontenenes by
}

255 s, ill. Oslo: Kolofon forlag, 2014.

Pris NOK 450

ISBN 978-82-300-1181-2

Det er skrevet et utall bøker om Roma. Kan det være marked for enda én? Etter å ha lest kollega Hugo Flatens bok er jeg ikke i tvil. Dette er en ny måte å beskrive Roma på.

Roma-fontenenes by er ikke bare en beskrivelse av fontenene, men også en fortelling om Romas vannforsyninger, akveduktene og badeanleggene, termene. Dette er en spennende vei inn i Romas mangfoldige historie. Boken er rikt illustrert, med opptil flere bilder på hver side. Det er gode tabellariske oversikter, for eksempel over akveduktenes historie. I tillegg er det en liste over de viktigste fontenemakerne.

Forfatteren er allmennpraktiserende lege i Oslo. Kanskje er det derfor han gjennom dette «con amore»-verket beskriver samfunnets avhengighet av (rent) vann på en så god måte? Han beskriver både vanntilførsel og avløp/kloakk. Den eldste akvedukten Aqua Appia ble påbegynt i $312 \mathrm{f} . \mathrm{Kr}$. Akveduktene hang sammen med vannledninger i bakken. Romas første kloakk Cloacus Maximus ble for øvrig bygd så langt tilbake som 500 år f.Kr. Antikkens romere hadde både private og offentlige vannklosett.

Det er lite igjen av oldtidens store badeanlegg, termene, men forfatteren gir oss likevel en levende beskrivelse av dem og de restene man kan se i dag.

Hovedtemaet, fontenene, er systematisk klassifisert og beskrevet. Et detaljert kart viser hvor de befinner seg, og hver fontene er beskrevet i detalj. De romerske fontenene er en munter og leken del av kunsthistorien. Det er guder og gudinner, sterke løver, flotte hester, tritoner (menneske og fisk), fisker som spruter, puttier (engler) som flyr, elegante delfiner, fabeldyr, kongler, bøker, kanonkuler og vintønner. Det er imponerende at romerne har greid å ta vare på alt dette i så lang tid.

Har romerne råd til å vedlikeholde denne «sløsingen» med vann? Det er blitt diskutert til alle tider. Da man omkring 1600 e.Kr. laget Skilpaddefontenen, måtte borgerne ta en ekstra skatt på kjøtt. I dag har egne etater ansvaret for regelmessig rengjøring og vedlikehold av fontenene.

Denne boken bør ikke være den første man leser som turist i Roma. Den egner seg best for dem som allerede har sett hovedattraksjonene, og som ønsker å studere detaljene nærmere, for dem som ønsker å sitte i ro på et torv eller på en uterestaurant ved siden av en fontene, som man så kan studere nærmere.

Jeg har bare en innvending, og det er at boken er for tung for en vanlig håndveske. Ta den i en liten ryggsekk, og bruk den som håndbok på reisen. Og skulle ikke en tur til Roma stå på dagsordenen, er dette den perfekte «coffee table book» for den som har vært der tidligere.

\section{Ingegerd Frøyshov Larsen}

Tidligere overlege, Lovisenberg Diakonale Sykehus Oslo 